\title{
STUDI IMPLEMENTASI STANDAR PROSES DALAM PEMBELAJARAN KURIKULUM 2013 PADA GURU SEKOLAH DASAR KABUPATEN MELAWI
}

\author{
Ason $^{1}$, Eko Fery Haryadi Saputro ${ }^{2}$ \\ ${ }_{1,2}$ Dosen STKIP Melawi \\ Jl. RSUD Melawi km. 04 Kec. Nanga Pinoh Kab. Melawi Kalimantan Barat \\ asonyakobus@gmail.com, feryiyadi06@gmail.com
}

\begin{abstract}
This study aims to determine the percentage of the level of teacher competence in implementing the 2013 curriculum, especially on the standard processes that include learning planning, the implementation of the learning process and the assessment of the learning process. This research was conducted at the Melawi Regency Elementary School, by taking 6 research samples from 258 elementary schools in Melawi Regency. This research was conducted for 3 months, from February to April 2019. The study used a descriptive qualitative approach with research subjects being teachers in several elementary schools in Melawi Regency. Data collection through a questionnaire that measures the level of competence of each teacher in implementing K-13, with the 5th sakala that is Very Appropriate (91-100\%); Appropriate (81-90\%), Fairly Adjusted (71-80\%), Less Adjusted (61-70\%) and Unsuitable (60\% $\geq$ ). The results of the study were analyzed by interactive analysis with the steps of reduction, presentation and verification. The results of this study indicate that, the competence of teachers in planning 2013 curriculum-based learning is as follows: those included in the good category amounted to $14 \%$, the categories were quite $61 \%$, and the category lacked $25 \%$. While the level of teacher competence in implementing the 2013 Curriculumbased learning process, the good category is $18 \%$, the category is $75 \%$, and the category is less $7 \%$. For the competence of teachers in carrying out 2013 curriculum-based learning evaluations, namely the good category $25 \%$, the category is $68 \%$, and the category is less $7 \%$. Thus it can be concluded that the average level of competence of Melawi Regency Elementary School teachers in understanding the 2013 curriculum, which includes learning planning, carrying out the learning process and conducting assessment of the learning process are good categories $19 \%$, $68 \%$ sufficient and less $13 \%$.
\end{abstract}

Keywords: Process Standards, Elementary School Teacher Learning

\begin{abstract}
Abstrak: Penelitian ini bertujuan untuk mengetahui prosentase tingkat kompetensi guru dalam mengimplementasikan Kurikulum 2013 khususnya pada standar proses yang meliputi perencanaan pembelajaran, pelaksanaan proses pembelajaran dan penilaian proses pembelajaran. Penelitian ini dilaksanakan di Sekolah Dasar Kabupaten Melawi, dengan mengambil 6 sampel penelitian dari 258 SD yang ada di Kabupaten Melawi. Penelitian ini dilaksanakan selama 3 bulan yakni dari bulan
\end{abstract}


Februari sampai dengan bulan April 2019. Penelitian menggunakan pendekatan kualitatif deskriptif dengan subyek penelitian adalah guru di beberapa SD di Kabupaten Melawi. Pengumpulan data melalui angket yang mengukur tingkat kompetensi guru masing-masing dalam mengimplementasikan K-13, dengan sakala 5 yakni Sangat Sesuai (91$100 \%)$; Sesuai (81-90\%), Cukup Sesuai (71-80\%), Kurang Sesuai (61$70 \%)$ dan Tidak Sesuai $(60 \% \geq)$. Data dianalisis dengan analisis interaktif dengan langkah-langkah reduksi data, penyajian data dan verifikasi data. Hasil penelitian ini menunjukkan bahwa, kompetensi guru dalam merencanakan pembelajaran berbasis Kurikulum 2013 adalah sebagai berikut: yang masuk dalam kategori baik sebesar 14\%, katagori cukup $61 \%$, dan kategori kurang 25\%. Sedangkan tingkat kompetensi guru dalam melaksanakan proses pembelajaran berbasis Kurikulum 2013 , kategori baik 18\%, katagori cukup 75\%, dan kategori kurang 7\%. Untuk kompetensi guru dalam melaksanakan evaluasi pembelajaran berbasis Kurikulum 2013 yaitu kategori baik 25\%, katagori cukup 68\%, dan kategori kurang $7 \%$.

\section{Kata Kunci: Standar Proses, Pembelajaran Guru Sekolah Dasar}

$\mathrm{P}$

erkembangan globalisasi menuntut lembaga pendidikan lebih memberikan pelayanan yang profesional kepada publik atau masyarakat. Hal ini disebabkan karena masyarakat sebagai pengguna jasa pelayanan sekarang ini semakin kritis. Di samping itu masyarakat berhak menentukan lembaga pendidikan sebagai tempat belajar yang layak bagi anak-anak mereka. Adapun harapannya lembaga pendidikan tersebut mampu memberikan generasi yang cerdas, profesional, dan berakhlakul sebagaimana tercantum pada tujuan pendidikan nasional.

Lembaga pendidikan dalam memberikan pelayanan yang profesional kepada publik tidak terlepas dari kinerja guru, karena baik atau tidaknya suatu pelayanan juga dilihat dari kinerja guru tersebut. Sebagaimana dalam UndangUndang No 20 Tahun 2003 tentang sistem pendidikan Nasional pada bab II pasal 3, bahwa pendidikan nasional berfungsi mengembangkan kemampuan dan membentuk watak serta peradaban bangsa yang bermartabat dalam rangka mencerdaskan kehidupan bangsa, bertujuan untuk mengembangkan potensi peserta didik agar menjadi manusia yang beriman dan bertakwa kepada Tuhan Yang Maha Esa, berakhlak mulia, sehat, berilmu, cakap, kreatif, mandiri dan menjadi warga negara yang demokratis serta bertanggung jawab (Departemen Agama, 2007:8).

Untuk merealisasikan tujuan pendidikan, maka sistem pembelajaran harus mengacu pada Standar Nasional Pendidikan. Pada Peraturan Pemerintah 
No 32 Tahun 2013 tentang perubahan Standar Nasional Pendidikan (SNP) atas Peraturan Pemerintah Nomor 19 Tahun 2005 Bab 1 pasal 1 ayat 7 dinyatakan bahwa Standar Nasional Pendidikan adalah kriteria minimal tentang sistem pendidikan di seluruh wilayah hukum Negara Kesatuan Replublik Indonesia yang bertujuan menjamin mutu pendidikan nasional dalam rangka mencerdaskan kehidupan bangsa dan membentuk watak serta peradaban bangsa yang bermatabat. (PP, No. 32 Tahun 2013)

Pemerintah terus berupaya meningkatkan kualitas pendidikan. Salah satu upaya tersebut adalah melalui perubahan dan pengembangan kurikulum. Perubahan dan pengembangan kurikulum perlu dilakukan karena kurikulum memiliki sifat yang dinamis agar mampu menjawab perkembangan dan tantangan zaman (E.Mulyasa 2013:135). Kurikulum mengarahkan segala bentuk aktivitas pendidikan untuk tercapainya tujuan pendidikan.

Bentuk aktivitas pendidikan tersebut dilakukan melalui suatu proses pembelajaran sehingga siswa diarahkan untuk mencapai tujuan dan dikembangkan segenap potensinya (Kwartolo 2007). Oleh karena itu, kurikulum memiliki peran penting sebagai pedoman bagi guru dalam menyelenggarakan kegiatan belajar mengajar.

Pada tahun ajaran 2013/2014, pemerintah telah mengimplementasikan kurikulum 2013. Implementasi kurikulum 2013 masih dilakukan secara terbatas dan bertahap di beberapa sekolah piloting dan beberapa jenjang pendidikan, yaitu dimulai dari kelas I dan IV SD, kelas VII SMP, dan kelas $\mathrm{X}$ SMA. Menurut Iskandar (2013), sosialisasi dan persiapan kurikulum 2013 yang dilakukan pemerintah dirasa kurang maksimal. Hal tersebut membuat keraguan banyak pihak mengenai implementasi kurikulum 2013 di lapangan.

Kurikulum 2013 memuat empat elemen perubahan, yaitu perubahan Standar Kompetensi Lulusan, Standar Proses, Standar Isi, dan Standar Penilaian (Permendikbud 2016). Salah satu standar pendidikan yang penting adalah Standar Proses. Standar Proses pendidikan adalah standar nasional pendidikan yang berkaitan dengan pelaksanaan pembelajaran pada satu satuan pendidikan untuk mencapai Standar Kompetensi Lulusan (Permendikbud No 22 Tahun 2016).

Standar Proses digunakan sebagai pedoman guru dalam pengelolaan pembelajaran karena berisi tentang standar minimal mengenai proses pembelajaran 
yang harus dilakukan. Meskipun telah disediakan panduan berupa Standar Proses, kesuksesan penerapannya di lapangan sangat dipengaruhi oleh kompetensi/kemampuan guru yang akan menerapkan dan mengaktualisasikan Standar Proses tersebut dalam pembelajaran.(Wina Sanjaya, 2014:91) Menurut data Laporan Akuntabilitas Kinerja Kemendikbud Tahun 2014 akses pendidikan di Indonesia masih perlu mendapat perhatian, masih berjumlah $1,1 \%$ anak tiap tahun tidak dapat melanjutkan sekolah. Sementara dari sisi kualitas guru dan komitmen mengajar terdapat lebih dari 43,43\% guru memiliki standar kualifikasi yang perlu ditingkatkan. (LAKIP Kemendikbud: 2014)

Standar Proses dapat dideskripsikan setiap satuan pendidik melakukan perencanaan pembelajaran (meliputi penyusunan Rencana Pelaksanaan Pembelajaran dan penyusunan Silabus), melakukan proses pembelajaran ( proses pembelajaran diselenggarakan secara interaktif, inspiratif, menyenangkan, menantang, memotivasi peserta didik untuk berpartisipasi aktif, serta memberikan ruang yang cukup bagi kreatifitas, prakarsa dan kemandirian sesuai dengan bakat, minat, dan perkembangan fisik serta psikologis peserta didik), melakukan penilaian hasil pembelajaran dan melakukan pengawasan proses pembelajaran untuk terlaksananya proses pembelajaran yang efektif dan efisien.( Permendikbud No. 22 Tahun 2016)

Kurikulum 2013 memiliki ciri khas, antara lain kegiatan pembelajaran menggunakan pendekatan saintifik; pembentukan sikap, pengetahuan, dan keterampilan secara terpadu; dan penanaman pendidikan karakter yang merupakan bagian dari Standar Proses. Salah satu kunci sukses dan berhasilnya kurikulum 2013 ditentukan oleh kreativitas guru dalam mengimplementasikannya. Oleh karena itu, peran guru dalam implementasi kurikulum sangat penting (E. Mulyasa:2013:9).

Berkenaan dengan pentingnya peran guru dalam proses pembelajaran, maka penelitian yang dilaksanakan menitik beratkan pada penerapan Standar Proses pembelajaran oleh Guru Sekolah Dasar Kabupaten Melawi. Dalam penelitian ini ada 3 (tiga) hal yang perlu dikumpulkan datanya melalui angket yaitu yang pertama perencanaan pembelajaran (RPP, Silabus), proses pembelajaran (rombongan belajar, sumber pembelajaran, pengelolaan kelas, pelaksanaan pembelajaran), dan penilaian hasil pembelajaran. Oleh karena itu 
peneliti mengkaji dalam sebuah penelitian tentang “ Studi Implementasi Standar Proses dalam Pembelajaran Kurikulum 2013 pada Guru Sekolah Dasar Kabupaten Melawi."

\section{METODE PENELITIAN}

Penelitian ini merupakan penelitian Kualitatif Deskriptif. Menurut pendapat Bogdan dan Taylor sebagaimana dikutip oleh Miftakhul Munir bahwa metodologi kualitatif sebagai prosedur penelitian menghasilkan data deskriptif berupa katakata tertulis atau lisan dari orang-orang dan perilaku yang dapat diamati (Moleong, 2007: 4).

Zuriah (2006: 82) mengatakan bahwa penelitian kualitatif bersifat generating theory bukan hypothesistesting, sehingga teori yang dihasilkan berupa teori subtantif dan teori-teori yang diangkat dari dasar (groundes theory). Penelitian ini termasuk dalam jenis penelitian kualitatif. Penelitian ini berusaha untuk mendeskripsikan atau menggambarkan data-data yang telah diperoleh dari lapangan maupun literatur kepustakaan yang berkaitan dengan pembahasan.

Teknik pengumpulan data dalam penelitian ini adalah teknik non tes dengan menggunakan instrumen angket. Angket adalah teknik pengumpulan data dengan cara mengajukan pertanyaan tertulis untuk dijawab secara tertulis pula oleh responden. Angket merupakan kumpulan pertanyaan-pertanyaan yang tertulis yang digunakan untuk memperoleh informasi dari responden tentang diri pribadi atau hal-hal yang ia ketahui. Angket adalah seperangkat pertanyaan tertulis yang diberikan kepada subjek penelitian untuk dijawab sesuai dengan keadaan subjek yang sebenarnya.

Angket dalam penelitian ini disusun berdasarkan kisi-kisi sebagai berikut:

Tabel . 1 Kisi-Kisi Instrumen Angket

\begin{tabular}{lll}
\hline \multicolumn{1}{c}{ Objek Penelitian } & \multicolumn{1}{c}{ Aspek Penelitian } & \multicolumn{1}{c}{$\begin{array}{c}\text { Nomor Butir } \\
\text { Pernyataan }\end{array}$} \\
\hline Implementasi Standar & Perencanaan Pembelajaran & $1-4$ \\
Proses Kurikulum 2013 & Pelaksanaan Pembelajaran & $5-12$ \\
& Penilaian Proses pembelajaran & $13-25$ \\
\hline
\end{tabular}

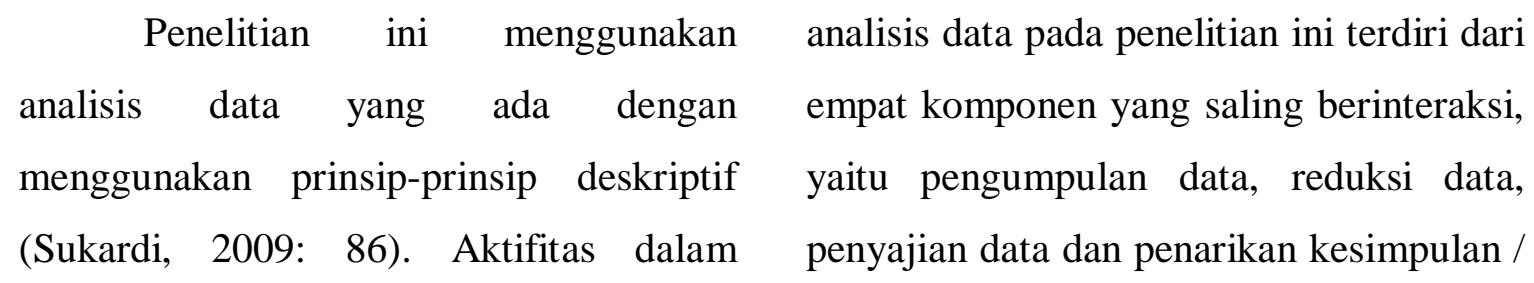


verifikasi. Teknik analisis data model interaktif dalam penelitian ini dijelaskan sebagaimana langkah-langkah berikut

\section{Pengumpulan Data}

Merupakan proses pencarian data yang dilakukan dengan cara menyebarkan angket tentang Inplementasi Standar Proses pada Kurikulum 2013 kepada para guru di Sekolah Dasar Kabupaten Melawi yang menjadi sampel penelitian.

\section{Penyajian Data}

\section{Sajian} data adalah mengorganisasikan data yang sudah direduksi, diberikan dalam bentuk narasi kalimat yang disusun secara logis dan sistematis mengacu pada rumusan masalah. Sajian data yang disampaikan berupa tabel dan analisis dari data pada tabel tersebut yang berupa narasi. Hal ini dimaksudkan agar pembaca penelitian ini dapat memahami isi penelitian dengan lebih jelas.

\section{Penarikan Kesimpulan dan Verifikasi}

Penarikan kesimpilan merupakan tahap akhir atas pola-pola atau konfigurasi tertentu dalam penelitian tertentu dalam penelitan ini sehingga menggambarkan secara utuh terhadap seluruh rangkian kegiatan penelitian. Kesimpulan atau verifikasi adalah upaya untuk mencari makna terhadap data yang dikumpulkan dengan mencari pola, tema, hubungan, persamaan, hal-hal lain yang sering timbul dan sebagainya.

\section{HASIL PENELITIAN}

Pada tahun 2017 yang lalu ada 104 sekolah di Kabupaten Melawi mulai menerapkan kurikulum 2013, namun penerapannya hanya pada kelas pemula, seperti kelas 1 SD, kelas IV SD, kelas VII SMP dan kelas X SMA/SMK. Dari 104 sekolah yang menerapkan kurikulum 2013 tersebut terdapat 70 Sekolah Dasar (SD), 27 Sekolah Menengah Pertama (SMP), dan 7 SMA dan SMK.. Penerapakn kurikulum 2013 pada tingkat Sekolah Dasar pada tahun 2017 dilaksanakan oleh 70 sekolah dari 258 sekolah dasar yang ada di Kabupaten Melawi.

Adapun 70 sekolah yang telah menerapkan Kurikulum 2013 pada tahun 2017 tersebut, di antaranya terdapat 6 sekolah dasar yang dijadikan sampel penelitian yaitu : SDN 14 Kelakik; (2) SDN 8 Nanga Potai; (3) SDN 3 Laja; (4) SDN 03 Nanga Kalan,; (5) SDN 07 Kebebu dan (6) SDN 12 Lintah. Keenam sekolah ini dijadikan sampel penelitian karena guru yang mengajar di sekolahsekolah tersebut terdapat beberapa alumni STKIP Melawi yang bisa diajak kerjasama dalam kegiatan penelitian dengan judul: "Studi Implementasi Standar Proses dalam Pembelajaran Kurikulum 2013 pada Guru Sekolah Dasar Kabupaten Melawi." 
Berdasarkan data yang didapatkan dari angket yang disebarkan, selanjutnya peneliti menganalisa data yang sudah terkumpul dengan menggunakan metode Diskritif Kualitatif yaitu menerangkan keadaan dengan kata-kata terperinci. Analisis data ini dilaksanakan untuk mengungkapkan hal-hal tentang Standar Proses dalam pembelajaran kurikulum 2013 di Sekolah Dasar Kabupaten Melawi. Dalam meningkatkan Standar Proses pembelajaran setiap guru mempunyai beberapa strategi yang dilakukan diantaranya:

\section{Perencanaan Proses Pembelajaran}

Sesuai dengan Permendikbud No. 22 Tahun 2016 tentang Standar Proses, perencanaan proses pembelajaran meliputi silabus dan Rencana Pelaksanaan Pembelajaran (RPP).(Permendikbud No. 22 Tahun 2016). Pada umumnya penyusunan RPP dilakukan oleh guru melalui Kelompok Kerja Guru (KKG) Kecamatan, kemudian dikembangkan secara mandiri sesuai dengan kebutuhan pembelajaran. Dokumen tersebut telah tersusun berdasarkan Standar Kompetensi Lulusan dan Standar Isi untuk satuan pendidikan dasar dan menengah sesuai dengan pola pembelajaran pada setiap tahun ajaran tertentu.

Dalam penyusunan RPP juga menggunakan sumber buku dan juga dokumen pendukung, sumber buku meliputi materi pelajaran, internet adapun dokumen pendukung yaitu Permendikbud No. 22 Tahun 2016 sebagai acuan dalam penyusunan RPP. Selain itu RPP disusun juga bertujuan supaya perserta didik mampu menguasai kompetensi dasar dalam aspek afektif (sikap), kognitif (pengetahuan), dan psikomotor (keterampilan).

Senada dengan apa yang terlampir dalam Permendikbud No. 22 Tahun 2016 tentang Standar Proses menjelaskan bahwa pengembangan RPP dapat dilakukan oleh guru secara mandiri dan/atau secara bersama-sama melalui $\mathrm{KKG}$ di dalam suatu sekolah tertentu difasilitasi dan disupervisi kepala sekolah atau guru senior yang ditunjuk oleh kepala sekolah. Penyusunan RPP yang dilakukan secara musyawarah melalui $\mathrm{KKG}$ di sekolah membuat guru saling bertukar pikiran sehingga guru yang belum mengikuti pelatihan kurikulum 2013 memperoleh informasi dari guru yang telah mengikuti pelatihan.

Dengan adanya pergantian kurikulum dari kurikulum KTSP berganti kurikulum 2013, ada beberapa hal yang berbeda dalam perencanaan pelaksanaan pembelajaran. Dari mulai yang semula menyusun silabus, sekarang hanya memahami silabus karena sudah ada dari 7| J P D, p-IS S N : 2252-8156, e - I S S N : $2579-3993$ 
pusat hanya tinggal mengembangkan

Hasil penelitian mengenai kedalam RPP, selain itu formatnya yang kemampuan guru dalam menyusun RPP berbeda dengan kurikulum sebelumnya, berdasarkan angket yang disebarkan materi pelajaran yang baru sehingga perlu untuk menguasai dan memahami materi menunjukkan kriteria sebagai berikut, yakni $15 \%$ berkemampuan baik, $61 \%$ pelajaran tersebut. cukup, dan $25 \%$ kurang sesuai dapat dilihat pada tabel berikut :

Tabel 2 Perencanaan Pembelajaran Guru

\begin{tabular}{lc}
\hline Tingkat Kesesuaian & Persentase \\
\hline Sangat Baik & $0 \%$ \\
Baik & $14 \%$ \\
Cukup & $61 \%$ \\
Kurang & $25 \%$ \\
Sangat Kurang & $0 \%$ \\
\hline
\end{tabular}

\section{Pelaksanaan Proses Pembelajaran}

Dalam pelaksanaan pembelajaran ada persyaratan yang harus di penuhi diantaranya:

a. Alokasi waktu jam tatap muka pembelajaran

Menurut Permendikbud No. 22 Tahun 2016 tentang Standar Proses pelaksanaan pembelajaran dalam alokasi waktu jam tatap muka pembelajaran untuk satuan pendidikan tingkat sekolah dasar adalah 35 menit.( Permendikbud No. 22 Tahun 2016)

Senada dengan permendikbud diatas Guru SD Kabupaten Melawi telah memperhatikan alokasi waktu jam tatap muka pembelajaran dalam pelaksanaan pembelajaran selama 35 menit sehingga hal tersebut menunjukkan bahwa pelaksanaan proses pembelajaran sudah berjalan dengan baik dan sesuai tujuan pembelajaran.

b. Rombongan belajar

Jumlah rombongan belajar dalam satuan pendidikan sekolah dasar adalah 6 24 dan jumlah maksimum peserta didik dalam setiap rombongan belajar adalah 28 . Adapun jumlah rombongan belajar di enam sekolah yang dijadikan sampel penelitian adalah masing-masing 6 kelas, sedangkan jumlah guru yang dijadikan subyek penelitian adalah berjumlah 28 orang.

c. Buku teks pelajaran

Buku teks pelajaran yang digunakan Di Sekolah Dasar yang dijadikan sempale penelitian ini adalah sudah sesuai dengan jumlah dan 
kebutuhan peserta didik. Sehingga setiap peserta didik sudah mempunyai buku teks pelajaran yang dipelukan. Pelaksanaan pembelajaran di sekolah-sekolah tersebut secara umum telah sesuai dengan RPP yang disusun. Guru selalu berusaha membuat pembelajaran berlangsung sesuai RPP agar dapat mengetahui kekurangan dan kelebihan selama proses pembelajaran. Dengan berpedoman pada RPP, guru dapat mengajar secara sistematis, tanpa khawatir keluar dari

\begin{tabular}{ll}
\hline Tingkat Kesesuaian & Persentase \\
\hline Sangat Baik & $0 \%$ \\
Baik & $18 \%$ \\
Cukup & $75 \%$ \\
Kurang & $7 \%$ \\
Sangat Kurang & $0 \%$ \\
\hline
\end{tabular}

\section{Penilaian Hasil Pembelajaran}

Pelaksanaan penilaian hasil belajar memuat penilaian sikap (afektif), kognitif (pengetahuan), dan psikomotor (keterampilan). Penilaian tersebut bertujuan untuk mendapatkan gambaran perkembangan peserta didik dalam mencapai kompetensi dasar yang telah direncanakan dalam RPP.

a. Merencanakan penilaian

Penilaian yang dirancang guru dalam RPP telah disusun secara lengkap untuk menilai sikap, pengetahuan, dan keterampilan. Namun demikian, dalam pelaksanaannya guru belum sepenuhnya tujuan, ruang lingkup materi, strategi pembelajaran, atau keluar dari sistem evaluasi yang seharusnya dilakukan.

Hasil penelitian terhadap kemampuan guru dalam melaksanakan pembelajaran sesuai dengan RPP yang mereka susun juga dapat dijabarkan sebagai berikut, yakni $18 \%$ berkemampuan baik, $75 \%$ cukup, dan $7 \%$ kurang sesuai dapat dilihat pada tabel berikut:

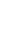


siswa secara langsung, tes tertulis jumlah nilai maka hasilnya akan menjadi dilakukan pada akhir pembelajaran untuk mengukur kompetensi pengetahuan peserta didik, tes praktek yang dilakukan pada pembelajaran praktek yang bertujuan untuk mengukur kompetensi keterampilan peserta didik, dan tes pengamatan untuk mengukur kompetensi sikap peserta didik dengan mengamati satu persatu sikap, tingkah laku dan kepribadian peserta didik. Penilaian dilakukan selama pembelajaran berlangsung dan setelah pembelajaran selesai dilakukan penilaian hasil dengan ulangan harian sampai peserta didik mencapai kompetensi yang ditetapkan.

c. Pengolahan hasil penilaiaian

Hasil nilai yang diolah oleh guru didapat dari gabungan nilai tugas, nilai nilai akhir dengan bobot masing-masing yang distandarkan dengan KKM. Peserta didik dinyatakan menguasai kompetensi jika mencapai atau melebihi nilai KKM yang ditetapkan untuk setiap mata pelajaran. Nilai tersebut sudah mencakup nilai sikap,pengetahuan, dan keterampilan. Senada dengan Permendikbud No 22 Tahun 2016 tentang Standar Proses bentuk penilaian aspek sikap, penilaian aspek pengetahuan dan penilaian aspek ketrampilan.

Hasil penelitian terhadap kemampuan guru dalam melaksanakan penilaian proses dapat dijabarkan sebagai berikut, yakni $18 \%$ berkemampuan baik, $75 \%$ cukup dan $7 \%$ kurang sesuai dapat dilihat pada tabel berikut : ulangan harian dan nilai ujian dibagi

Tabel 4 Pelaksanaan Proses Pembelajaran Guru

\begin{tabular}{ll}
\hline Tingkat Kesesuaian & Persentase \\
\hline Sangat Baik & $0 \%$ \\
Baik & $25 \%$ \\
Cukup & $68 \%$ \\
Kurang & $7 \%$ \\
Sangat Kurang & $0 \%$ \\
\hline
\end{tabular}

\section{SIMPULAN}

Hasil penelitian ini menunjukkan bahwa, pemahaman guru tentang perencanaan pembelajaran berbasis Kurikulum 2013 yaitu yang masuk dalam kategori baik sebesar 14\%, katagori cukup $61 \%$, dan kategori kurang $25 \%$.
Sedangkan pemahaman dan kemampuan guru dalam melaksanakan proses pembelajaran berbasis Kurikulum 2013 yaitu yang masuk dalam kategori baik 18\%, katagori cukup 75\%, dan kategori kurang $7 \%$. Untuk pemahaman guru tentang evaluasi pembelajaran berbasis 10| J P D, p - I S S N : $2252-8156$, e - I S S N : $2579-3993$ 
Kurikulum 2013 yaitu yang masuk dalam kategori baik 25\%, katagori cukup 68\%, dan kategori kurang $7 \%$.

Dengan demikian dapat disimpulkan bahwa pemahaman guru Sekolah Dasar Kabupaten Melawi terhadap krikulum 2013, dalam merencanakan pembelajarn, melaksanakan proses pembelajaran dan melasanakan penilaian proses pembelajaran menunjukkan kategori baik $19 \%$, cukup $68 \%$ dan kurang $13 \%$.

\section{REFERENSI}

Fadillah, M. 2014. Implementasi Kurikulum $2013 \quad$ Dalam Pembelajaran SD/MI, SD/MTS, dan SMA/MA. Yogyakarta : Ar-Ruzz

Alawiyah, F. 2014. "Kesiapan Guru Dalam Implementasi Kurikulum 2013”. Jurnal Info Singkat Kesejahteraan Sosial. Vol. VI, No. 15. Diakses tanggal 12 Mei 2017.

Herdiansyah, H. 2012. Metodologi Penelitian Kualitatif untuk Ilmu-ilmu Sosial. Jakarta Selatan : Salemba Humanika.

Kemdikbud. 2013. Materi Pelatihan Guru Implementasi Kurikulum 2013. Jakarta: Kemdikbud
Moleong, L. J. 2007. Metodologi Penelitian Kualitatif. Bandung: Remaja Rosdakarya

Mulyasa. 2013. Pengembangan dan Implementasi Kurikulum 2013. Bandung: Rosdakarya

Laksono, S. L. 2013. Implementasi Standar Proses Pembelajaran Pendidikan Kewarganegaraan Berdasarkan Peraturan Menteri Pendidikan Nasional Republik Indonesia Nomor 41 Tahun 2007 (Studi Kasus di SMP Negeri 2 Kedunggalar Kabupaten Ngawi tahun ajaran 2012/2013). Skripsi. Surakarta: UMS.

Sugiyono. 2015. Metode Penelitian Kuantitatif dan Kualitatif dan $R \& D$. Bandung: Alfabeta

Suharsimi, A. 2002. Prosedur Penelitian Suatu Pendekatan Praktik. Jakarta: PT Rineka Cipta.

Sukardi. 2009. Metodologi Penelitian Pendidikan Kompetensi dan Praktiknya. Jakarta: Bumi Aksara.

Undang - Undang Republik Indonesia Nomor 14 Tahun 2005 Tentang Guru Dan Dosen 